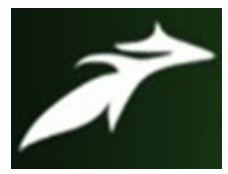

Khalid Ahmad Yaqoobi et al, International Journal of Advances in Agricultural Science and Technology, Vol.7 Issue.12, December-2020, pg. 65-70

ISSN: $2348-1358$

Impact Factor: 6.057

NAAS Rating: 3.77

\title{
Effects of Natural Zeolite Mineral on Chemical Properties of Saline Soil
}

\author{
Khalid Ahmad Yaqoobi ${ }^{1}$; Noorulhaq Mohammadi ${ }^{2}$; Shershah Rashad ${ }^{3}$; Ahmad Fawad \\ Ehsas $^{4}$; Dr. Farshd Kaini ${ }^{5}$; Shah Mahmood Baray ${ }^{6}$; Mohammad Haroon Rahimi ${ }^{7}$; \\ Khalilullah Zaryal ${ }^{8}$; Sayed Ahmad Sayedi'; Attiqullah Aiaz ${ }^{10}$; Naser Ahmad Nasrat ${ }^{11}$ \\ Assistant Professor, Department of Agronomy, Faculty of Agriculture, Afghanistan National Agricultural Science and \\ Technology University (ANASTU)- Afghanistan, Kandahar \\ Corresponding Author's Email: Kyaqubi3@gmail.com
}

DOI: 10.47856/ijaast.2020.v07i12.010

\begin{abstract}
The utilization of Zeolite minerals has recognized as new technology of recent few years, which decreases negative effect of chemical and nitrogen fertilizer with causes chemical, biological, physical and hydrological recovery of soil. Additionally, Zeolite decreases soil and underground water pollution, as well as it's a good amendment of soil and water. The goal of the study is, the effect of natural zeolite on part of soil traits on chemical properties. In this research three treatments (Zeolite $20 \%$ plus $80 \%$ soil, Zeolite $10 \%$ plus $90 \%$ soil, and Soil (control) in three replications were used. Soil into pots treated and remains for ten days, then some parameters soil reaction (pH), Electric Conductivity (EC), organic matter (OM), lime, Cation Exchange Capacity (CEC) and exchangeable sodium) was measured. Result revealed different amount of zeolites effect on soil, pH, $E C, O M$, lime, $C E C$, exchangeable sodium, showed significant difference $(P \geq 0.05)$ in each of them.
\end{abstract}

Keywords: Zeolite, Soil, reaction, CEC, OM, lime and EC

\section{Introduction}

Zeolite was discovered by Swedish mineralogist, Baron Excel Fredrik on 1756. With observing its amazing characteristics was nominated mineral stone in Greek language. Until now more than 85 types of natural zeolite and more than 100 types of artificial zeolite synthesized (Ghazavi, et al., 2012). Zeolites are crystalized hydrated ammonium silicate, which mainly effect on CEC, and soil surface absorbance. And affectively uses for separation of toxic elements from contamination water. In last decades much attempts for the utilization of cheap sources for cleaning of huge metal contaminated soil, water and industrially contaminated water from those mines cleaning material. Zeolites are broadly usages (He and Huang, 2013).

Zeolites utilization benefits in agriculture are quantitative and qualitative developing of soil and agricultural products, enhances plant growing position, plant turgor, reductions in irrigation volume, decreases of evaporation, phosphorous absorbance increment in sandy and gravely soil, decline of nitrogen leaching from soil by irrigation and rain water, support of oxygen and soil aeration, with some ion preparation such as, $\mathrm{P}, \mathrm{Ca}, \mathrm{Mg}$ and assist clean soil from toxic and huge elements, has particular effect on different plant nutrition and could have positive effect on growth besides development of plant production, and fruits quality (Leonard et al., 1981).

Zeolite as soil developmental of suitable agent for CEC, and water absorbance could have better place. Leaching of nitrate from soil is not only waste of money but as well as creation of water resource contamination problem. Therefor several methods for prevention of nitrate leaching prescribed, but because of expensiveness and less usefulness of them are not welcomed. Therefor the utilization of zeolite as cheap substance with high performance of working is considered to be used (Barnard et al., 2012). The study of Tsintskaladze, (2017) revealed that in last years the new method for small scale is the utilization of zeolite, which decreases the negative effect of nitrogen fertilizer. Furthermore, zeolite decreasing underground water contamination, and good amendments for soil and 


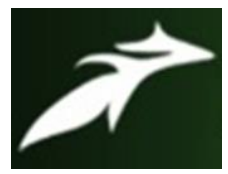

Khalid Ahmad Yaqoobi et al, International Journal of Advances in Agricultural Science and Technology, Vol.7 Issue.12, December-2020, pg. 65-70

ISSN: $2348-1358$

Impact Factor: 6.057

NAAS Rating: 3.77

water (Milosevic et al., 2002). Their study displayed the effect of cow manure, NPK with combination of (15:15:15) plus natural zeolite on soil properties, plant growth and potato response in the vertisole soil. The result showed, mentioned combination could decline soil acidity, increase of humus portion, over all nitrogen, in resulted to increase soil phosphorous and potassium. Besoudi et al., (2008) also displayed that zeolite could significantly decrease EC effect and contribution to make soil nutrient balance into saline soil. Noori and Zendadile (2006) studied the effect of natural zeolite on soil EC and salinity on Raphanus sativus L. crop, treated with natural zeolite, $\mathrm{Na}_{2} \mathrm{SO}_{4}, \mathrm{NaCl}$, control, zeolite plus $\mathrm{NaCl}$ and zeolite plus $\mathrm{Na}_{2} \mathrm{SO}_{4}$. The result expressed natural zeolite treated plant better yield and soil amendment, correspondingly zeolite does not let salt to move into plant root. The goal of this experiment was to study the effect of natural zeolite on chemical properties (soil pH, EC, OM, lime, CEC, exchangeable Sodium) of soil.

\section{Material and Method:}

This experiment was conducted in the Gorgan University, faculty of agriculture and natural resources of Gorgan, on 2018-2019. With consideration to soil importance, which would come under study, attempts to find arable saline soil.

First area of study: soil sampling from $30 \mathrm{~cm}$ depth of surface soil of urban growing area Marawa Tapa (57' 55 " N to 55 ' 28 " E) was handed.

Second: Zeolite as powder from soil Sia Zagh Saman in three level $(0,10$, and 20\%) with combination of saline soil, and the combination of treatments of ten days, mixed into each single part as chart1 and after ten days' chemical parameters of soil was studied. (EC by EC mater, organic matter with wallky black (Nelson and Samar., 1982), lime via titration, $\mathrm{pH}$ by $\mathrm{pH}$ mater and soil extract (Black, 1965) exchangeable sodium with extraction method with ammonium acetate and CEC by Boyer method ware measured (Morgan, 2005).

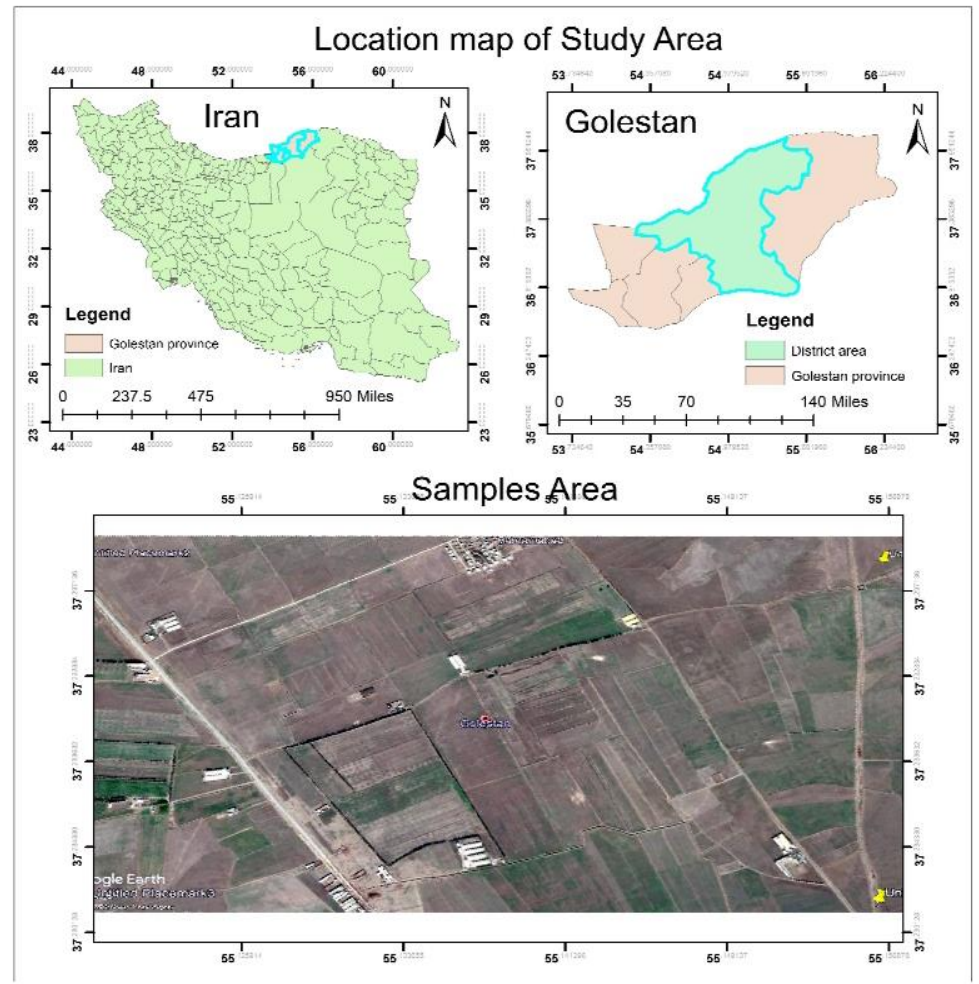

Figure. (1) Location Map of Study Area 


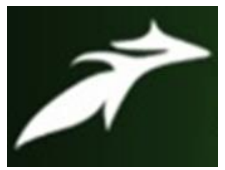

Khalid Ahmad Yaqoobi et al, International Journal of Advances in Agricultural Science and Technology,

Vol.7 Issue.12, December-2020, pg. 65-70

ISSN: $2348-1358$

Impact Factor: 6.057

NAAS Rating: 3.77

Table (1): Combination of studied treatments

\begin{tabular}{c|ccc} 
No & Treatments & Combination & Replication \\
\hline 1 & Soil(control) & Control & 3 \\
\hline 2 & $10 \%$ zeolite & $10 \%$ zeolite $+90 \%$ soil & 3 \\
\hline 3 & $20 \%$ zeolite & $20 \%$ zeolite $+80 \%$ soil & 3 \\
\hline
\end{tabular}

Data analysis: From the data analysis, statistical results were performed by SAS software. For significance difference $(\mathrm{p}<0.05)$ ANOVA test and comparison of mean by Lsd test were used.

\section{Results and discussion}

Using the methods mentioned in the materials and methods section, the analysis of soil chemical properties and treatments were determined and the results of these experiments are obtained in Table (2). Table (2) shows the effect of factors of different levels of zeolite on the soil $\mathrm{pH}, \mathrm{EC}, \mathrm{OM}$, lime, CEC and exchangeable sodium. As can be seen, different levels of zeolite at the level of $1 \%$ separately had a significant effect $(\mathrm{P}<0.5)$

Table 2: Analysis of variance of the effect of zeolite on some soil chemical properties

\begin{tabular}{|c|c|c|c|c|c|c|c|}
\hline Sources & $\begin{array}{l}\text { Degree of } \\
\text { freedom }\end{array}$ & $\mathrm{pH}$ & $\mathrm{EC}$ & O.M & Lime & CEC & $\mathrm{Na}$ meq $/ 1$ \\
\hline Replication & 2 & $0,001^{\mathrm{ns}}$ & $0,0.31^{\mathrm{ns}}$ & $0,01 \mathrm{~ns}$ & $0,04^{\mathrm{ns}}$ & $0,43^{\text {ns }}$ & $0,002^{\text {ns }}$ \\
\hline Treatment & 3 & $0,14^{*}$ & $10,99 * *$ & $1,01 *$ & $0.61 *$ & $602,04 * *$ & $1.308 * *$ \\
\hline Error & 6 & 0,006 & 0.05 & 0,001 & 0.07 & 1,41 & 0,003 \\
\hline C.V & & 1,05 & 1,12 & 17,64 & 1,60 & 4.85 & 1,61 \\
\hline
\end{tabular}

*And** indicates the difference in significances, and ns indicates the lack of significances- pH: Soil reaction, EC: Electric conductivity (Soil salinity)s, O.M: Soil organic matter, Lime: Soil lime, CEC: Cation exchange capacity.

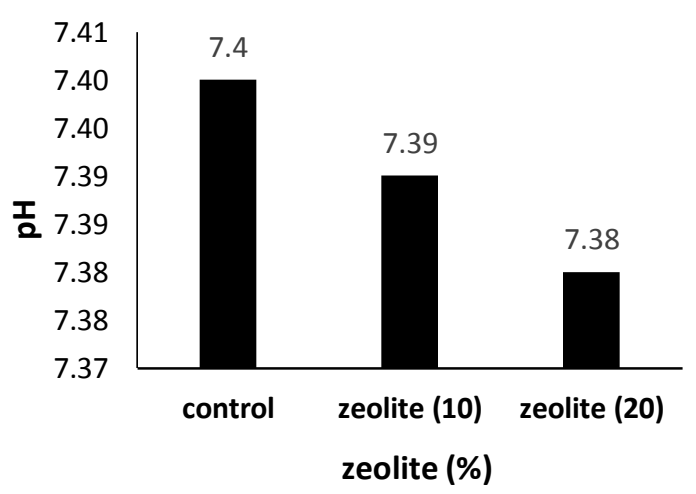

Figure (2) Effects of different percentage of zeolite treatments on Soil pH

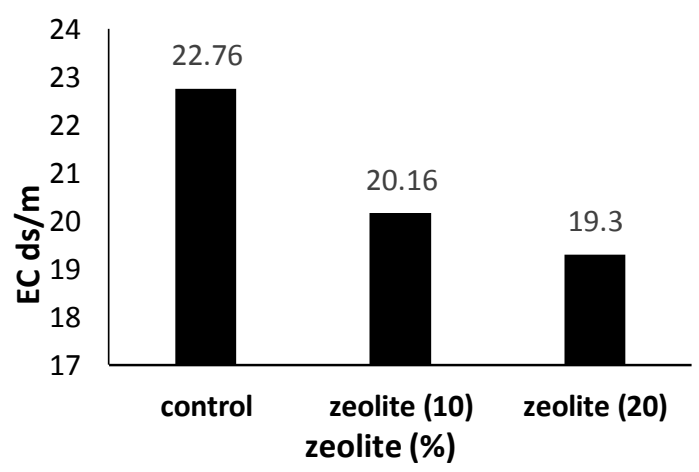

Figure (3) Effects of different percentage of zeolite treatments on Soil EC 


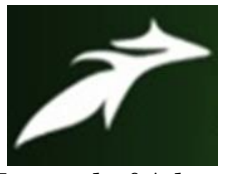

Khalid Ahmad Yaqoobi et al, International Journal of Advances in Agricultural Science and Technology,

Vol.7 Issue.12, December-2020, pg. 65-70

ISSN: $2348-1358$

Impact Factor: 6.057

NAAS Rating: 3.77

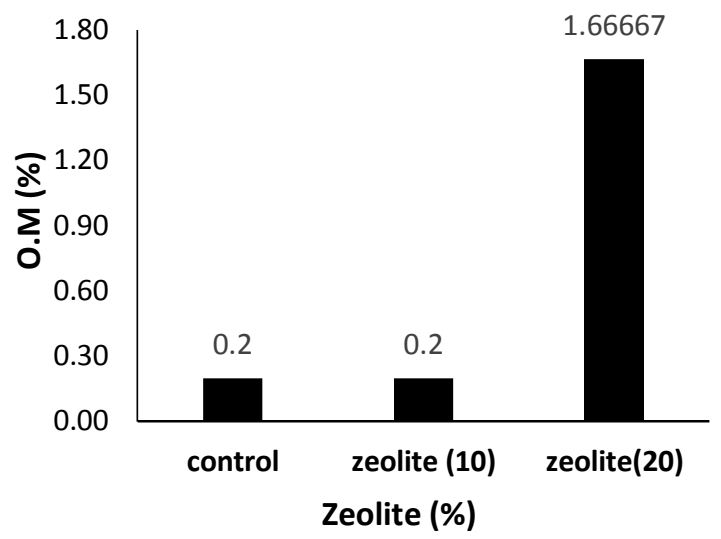

Figure (4) Effects of different percentage of zeolite treatments on Soil Organic Mater

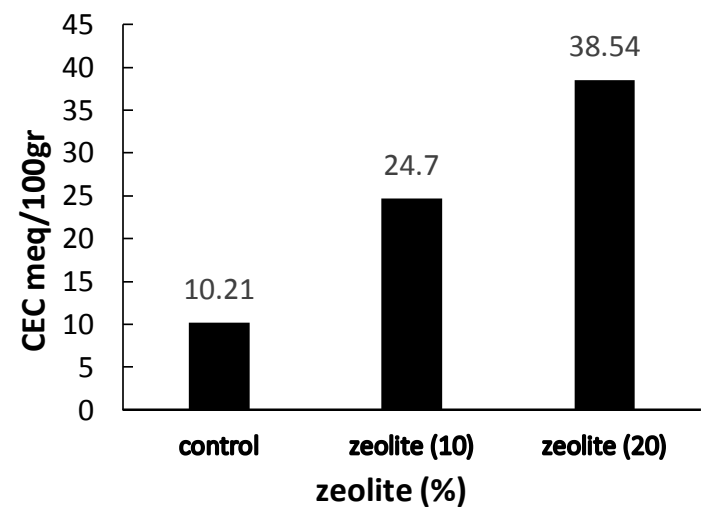

Figure (6) Effects of different percentage of zeolite treatments on Soil Cation Exchange

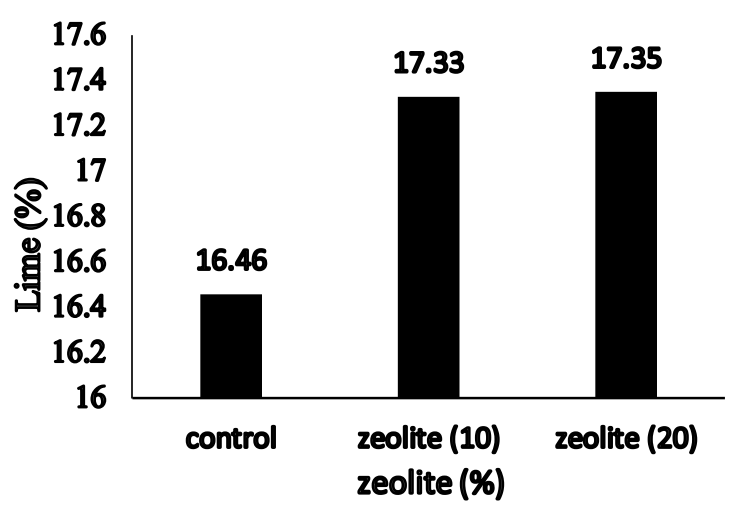

Figure (5) Effects of different percentage of zeolite treatments on Soil Lime

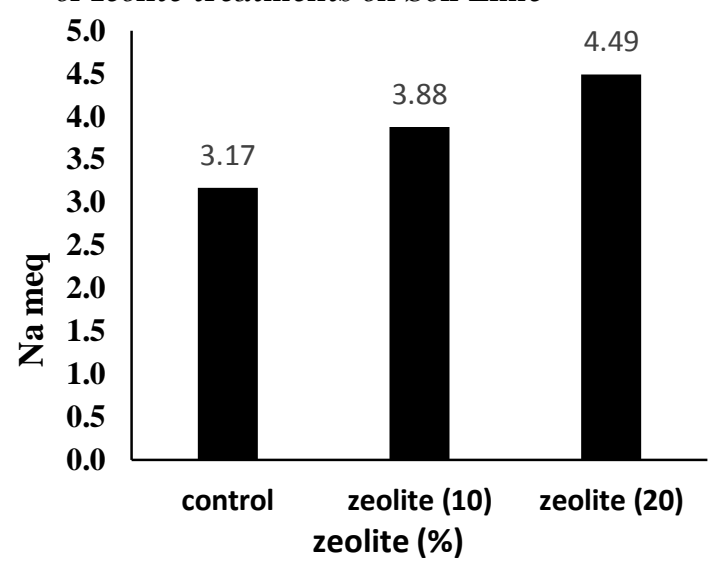

Figure (7) Effects of different percentage of zeolite treatments on Soil Exchangeable $\mathrm{Na}$

Figure (2) shows the effect of different amounts of zeolite on soil reaction rate (pH). As can be seen, soil $\mathrm{pH}$ was significantly decreased in 10 and $20 \%$ zeolite treatments compared to the control $(\mathrm{pH} 7.4)$ to 7.39 and 7.38 respectively. These findings are consistent with the results of Akbar et al. (2014), who stated that the use of zeolite as a buffer reduces soil reaction.

The effect of different amounts of zeolite on soil salinity is clarified in Figure (3). As displayed, treatments of 10\% and $20 \%$ zeolite significantly reduced $\mathrm{EC}$ as soil salinity $(\mathrm{P}<0.05)$. In which salinity decrease was about 11.42 and $16.38 \%$ respectively. These findings are consistent with stated results in which zeolite had a great effect on soil salinity, adding zeolite causes the absorption of harmful salts and reduces soil salinity stress (Al-Busaidi et al., 2008).

The influence of zeolite volume variation on soil organic matter is shown in Figure (4). Zeolite behaviors of 10 and $20 \%$ had effect on soil OM compared to the zero treatments. The soil which treated by $10 \%$ didn't had meaningful impact on OM. In contrast, $20 \%$ zeolite was affected remarkably positive and displayed an increase of $15.7 \%$ compared to the control. Same as mentioned stated outcomes, that giving additional soil OM increases soil 


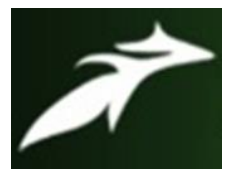

Khalid Ahmad Yaqoobi et al, International Journal of Advances in Agricultural Science and Technology, Vol.7 Issue.12, December-2020, pg. 65-70

ISSN: $2348-1358$

Impact Factor: 6.057

NAAS Rating: 3.77

roughness, as a result of which, water penetrates into the soil to a great extent (Behzad Far et al., 2017).

Figure (5). shows the effect of different amounts of zeolite on the amount of lime. The usages of 10 and $20 \%$ zeolite significantly increased the percentage of soil lime in contrast to the zero treatment, which an increase of 3.5 and $4.7 \%$ was accrued. These findings are consistent with the results of Khodaei-Joghan et al. (2012), who specified that zeolites are full of cations such as sodium $\left(\mathrm{Na}^{+}\right),(\mathrm{K}+)$ and $(\mathrm{Ca}+)$ and high concentrations of heavy metals which increase lime.

Figure (6). shows the effect of different amounts of zeolite on the amount of cation exchange capacity. In comparison to the control, treated soil by 10 and $20 \%$ of zeolite considerably, in what CEC raised for 58.66 and $73.50 \%$ respectively. These results are steady with the results of Mempton (1999). Mempton indicated that zeolites have high CEC capacity and water absorption properties, and are a better soil drainage.

Figure (7). demonstrated the effect of zeolite content on soil exchangeable Sodium. As can be seen, behaviors of 10 and $20 \%$ zeolite significantly improved the volume of exchangeable sodium by $22.3 \%$ and $41.4 \%$ in comparison to the control soil. These findings are consistent with the results of Khodaei-Joghan et al. (2012), he stated that zeolite with negative charge causes the adsorption of monovalent cations such as $(\mathrm{Na}+),(\mathrm{K}+)$ and $(\mathrm{Ca}+)$.

\section{Conclusion}

Chemical and measured properties of soil after adding treatments to soil included soil reaction, soil salinity, percentage of organic matter, lime, cation exchange capacity and soil exchangeable sodium. The results showed that all treatments were able to significantly reduce soil $\mathrm{pH}$ and salinity, as well mixture of $20 \%$ increased organic matter, and 10 and $20 \%$ treatment improved lime, cation exchange capacity and exchangeable sodium.

\section{Recommendation}

1. It is suggested that a similar study be conducted in Kandahar province during different years.

2. It is suggested to use a combination of other organic and inorganic modifiers with zeolite.

3. Suggested that the use of zeolite to improve saline soils gave very good results and was a good fertilizer.

4. It is suggested that zeolite has a high cation exchange capacity and plays an important role in water absorption.

5. Zeolite is a soil modifier, its use is recommended in the field of sustainable agriculture, soil and water protection and the environment.

\section{REFERENCES}

[1]. Akbar, S., Khatoon S, Shehnaz R. \& Hussain, T. (1999) Natural Zeolites: Structures, Classification, Origin, Occurrence and Importance. Science International (Lahore), 11: 73-78.

[2]. Al-busaidi, A., Yamamoto, T., Inoue, M., Enji, A, E., Mori, Y. \& Irshd, M (2008). Effects of Zeolite on Soil Nutrients and Growth of Barley Following Irrigation with Saline Water. J. plant nutration,31(7), 1159-1173.

[3]. Bastida, F., Kandeler, E., Moreno, J., Ros, M., García, C. \& Hernández, T. (2008). Application of Fresh and Composted Organic Wastes Modifies Structure, Size and Activity of Soil Microbial Community Under Semiarid Climate. Applied Soil Ecol 40:318-329. doi:10.1016/ j. ap soil.2008.05.007

[4]. Behzadfar, M., Sadeghi, S, H., Khanjani, M., Javed., \&, Hazbavi, Z. (2017). Effects of Dates and Time of Zeolite Application on Controlling Runoff Generation and Soil Loss from a Soil Subjected to Freeze-Thaw cycle, Journal of Soil and Water Conservation Research 5(2017) 95-101.

[5]. Black, C.A. (1965). Methods of Soil Analysis. Part 1, American Society of Agronomy, No: 9.

[6]. Ghazavi, R., Vali, A.B., \& Eslamian, S. (2012). Impact of Flood Spreading on Groundwater Level Variation and Groundwater Quality in an Arid Environment. Water resources management 26 (6):1651-1663.

[7]. He, X., \& Huang, Z. (2001). Zeolite Application for Enhancing Water Infiltration and Retention in Loess Soil Resources. Conservation and Recycling, 34, 45-52.

[8]. Khodaei-Joghan, A. \& Asilan, K.S. (2012). Zeolite Influences on Nitrate Leaching, Nitrogen-Use Efficiency, Yield and Yield Components of Canola in Sandy Soil. Archives of Agronomy and Soil Science, 58: 1149-1169. 


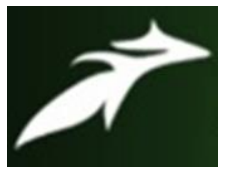

Khalid Ahmad Yaqoobi et al, International Journal of Advances in Agricultural Science and Technology,

Vol.7 Issue.12, December-2020, pg. 65-70

ISSN: $2348-1358$

Impact Factor: 6.057

NAAS Rating: 3.77

[9]. Leonard, J., Atlantic, J. \& Richfield, C. O. (1981). Preparation of Zeolite A by Hydrothermal Treatment of Clinoptilolite. U.S. Patent 4, 247,524.

[10]. Milosevic, T. \& Milosovec, N. (2009). The Effect of Zeolite, Organic Fertilizers on Soil Chemical Properties, Growth and Biomass Yield of Apple Trees. Journal of Plant Soil Environ (12): 528-535.

[11].Morgan, M.R.O.C., (2005). Soil Erosion and Conservation. Blackwell Sci. Ltd. Pub. USA.

[12]. Mumptun, Frederick A., (1999). La Roca Magica: Uses of Natural Zeolite in Agriculture and Industry, proc. natl. sci. 96, 3463-3470.

[13]. Noori, M., Mojgan, Zendehdel. \& Ahmadi, A. (2006). Using Natural Zeolite for Improvement of Soil Salinity and Crop Yield, Journal of Toxicological \& Environmental Chemistry, Jan-Mar. 2006; 88(1): 77-84.

[14]. Tsintskaladze, G., Eprikashvili, L., Urushadza, T., Kordzakhia, T., Sharashenidze, T., Zautashivili, M., \& Burjanadze, M. (2016). Nanomodified Natural Zeolite as a Fertilizer of Prolonoged Activity, Journal of annals of agrarian science $14,163-168$.

\section{Personal Information}

\begin{tabular}{|l|l|}
\hline Name & Khalid Ahmad Yaqoobi \\
\hline F/Name & Mohammad Nader \\
\hline Date of Birth & 15 July 1989 \\
\hline Place of Birth & Kandahar, Afghanistan \\
\hline Occupation & $\begin{array}{l}\text { Assistant Professor, Department of Agronomy, Faculty of Agriculture, } \\
\text { Afghanistan National Agricultural Science and Technology University } \\
\text { (ANASTU) }\end{array}$ \\
\hline Address & Kandahar City, Kandahar, Afghanistan \\
\hline
\end{tabular}

